\title{
GNREL
}

Hydrogen \& Fuel Cell Technical Highlights

\section{More Than 1,000 Fuel Cell Units Deployed Through DOE ARRA Funding}

\author{
Team: Jennifer Kurtz, Keith Wipke, Sam Sprik, Todd Ramsden, Chris Ainscough
}

Accomplishment: Early market end users are operating 1,111 fuel cell units at 301 sites in 20 states funded by the U.S. Department of Energy (DOE) Fuel Cell Technologies (FCT) Program and with analysis by the National Renewable Energy Laboratory (NREL).

Context: The American Recovery and Reinvestment Act (ARRA) funded the deployment of approximately 1,000 fuel cell systems in key early markets to accelerate the commercialization and deployment of fuel cells and fuel cell manufacturing, installation, maintenance, and support services. In support of the ARRA fuel cell deployment objectives, NREL analyzes and validates the technology in real-world applications, reports on the technology status, and facilitates the development of fuel cell technologies, manufacturing, and operations in strategic markets-including material handling equipment, backup power, and stationary power-where fuel cells can compete with conventional technologies.

Fuel Cell and Infrastructure Analysis: NREL is validating hydrogen and fuel cell systems in real-world settings through data collection, analysis, and reporting. The fuel cell and infrastructure analysis provides an independent, third-party assessment that focuses on fuel cell system and hydrogen infrastructure performance, operation, maintenance, use, and safety.

Significance of Accomplishment: An objective of the ARRA fuel cell project-to deploy approximately 1,000 fuel cell systems in key early markets - has been met in two years. By the end of 2011, 504 material handling equipment (MHE) fuel cell units were operating at 8 facilities and 607 backup power fuel cell units were operating at 293 sites. MHE and backup power are two markets where fuel cells are capable of meeting the operating demands, and deployments can be leveraged to accelerate fuel cell commercialization.

The fuel cell units are operating at end user sites under demanding real-world conditions, and they are demonstrating performance benefits like high reliability, ease of use, low or zero emissions, and productivity improvements. Fuel cell MHE units have accumulated more than 380,000 operation hours with good maintenance intervals and an average fill time of less than two minutes. A preliminary cost of ownership analysis indicates that the annualized cost of a fuel cell $\mathrm{MHE}$ is less than that of a comparable battery MHE for large fleets at high-use facilities. Backup power fuel cell units have demonstrated high reliability for successful starts, at $99.9 \%$, and nearly $60 \%$ of the starts are because of grid outages. These reliable backup power fuel cell units are operating in many different U.S. regions and are capable of long continuous run times with no emissions. At least one system has demonstrated a continuous operation of more than 29 hours.

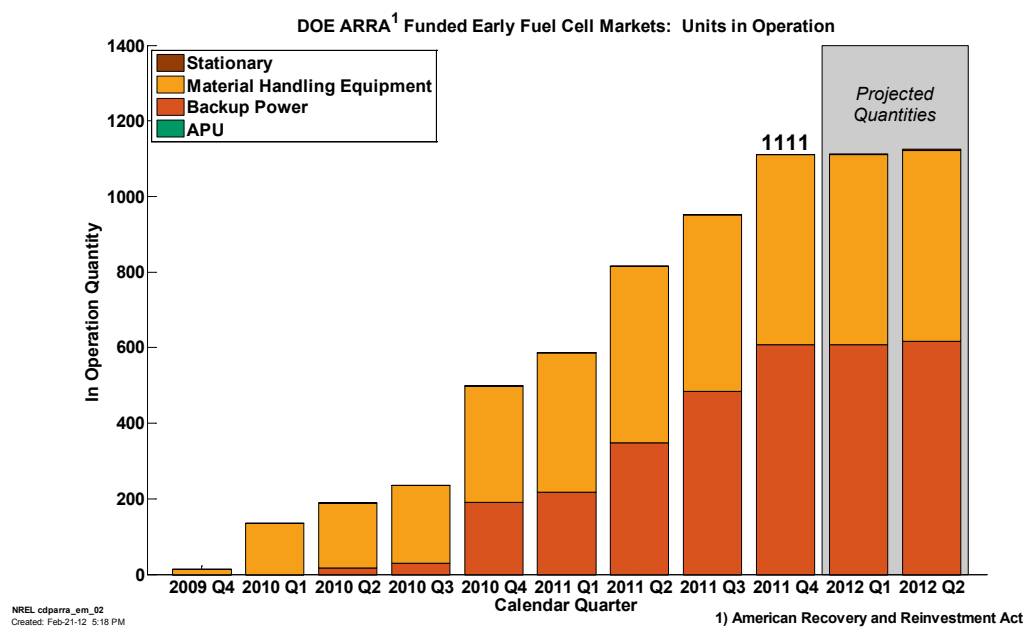

The number of fuel cell units in operation by calendar quarter increases quickly over two years

The deployment of 1,111 fuel cell units has established a significant data set of successful and safe operation in the hands of end users, has increased fuel cell manufacturing and support capabilities, and has translated lessons learned from the field into improved fuel cell systems for future operation.

For more information and the latest analysis results from NREL's fuel cell and infrastructure projects, visit the Hydrogen Technology Validation website at www.nrel.gov/hydrogen/proj tech validation.html. 